\title{
SUCROSE PHOSPHATE SYNTHASE GENE EXPRESSION IN SORGHUM, SWEET SORGHUM AND F5 HYBRID POPULATIONS
}

\author{
JI, Y. ${ }^{1}-$ ZhANG, W. T. ${ }^{1}-$ PANG, H. B. ${ }^{1}-$ LI, X. M. ${ }^{1}-$ MA, L. J. ${ }^{1}-$ WANG, L. L. ${ }^{1}-$ ZHANG, Y. ${ }^{1}-$ \\ HuSSAIN, K. ${ }^{3}-$ WU, S. W. ${ }^{2^{*}}-$ LI, Y. Y..$^{*}$ \\ ${ }^{1}$ College of Life Science, Shenyang Normal University \\ No. 253 Huanghe North Street, Shenyang, Liaoning 110034, China \\ ${ }^{2}$ College of Science Institute, Shenyang Agricultural University \\ No. 120 Dongling Road, Shenyang, Liaoning 110866, China \\ ${ }^{3}$ Department of Botany, University of Gujrat, HH Campus, Gujrat, Pakistan \\ *Corresponding authors \\ e-mail: wusuwen001@126.com, yueyinglicn@163.com \\ (Received $4^{\text {th }}$ Jul 2018; accepted $20^{\text {th }}$ Sep 2018)
}

\begin{abstract}
Sweet sorghum has drought resistance, waterlogging resistance, salt and alkali resistance, wide adaptability and excellent resistance to leaf diseases, and is one of China's important food crops, sugar crops and energy crops. In the face of the energy crisis, as an energy crop, sweet sorghum has a high conversion rate of ethanol, which shows an attractive prospect for development and utilization and has attracted the attention of many countries. One of the main indicators to measure the use value of sweet sorghum is its high sugar content, and it is of great significance to increase the sugar content. In this study, we examined the expression of sucrose phosphate synthase (SPS) in leaves of sweet sorghum and sorghum and found the rules of sugar accumulation in sweet sorghum. The effect of SPS gene expression on sucrose accumulation in sweet sorghum and the factors affecting the difference of sugar content between sweet sorghum and sorghum cultivars were studied. The sweet sorghum LTR102 (as the female in this experiment), and common grain sorghum 654 (as the male), and hybrid F5 high and low sugar individuals were used as experimental materials. The gene expression of sucrose phosphate synthase was detected by real-time PCR. According to the qualitative and quantitative analyses of SPS gene, the SPS gene is not only the key factor for the accumulation of sucrose, but also the factor that causes the difference in sugar content between sweet sorghum and common sorghum. At different growth stages, the high sugar individuals showed superiority in sucrose accumulation, SPS activity and SPS gene expression compared to the other three individuals.
\end{abstract}

Keywords: quantitative expression, $R T-P C R$, sucrose content, developmental stage

\section{Introduction}

With the increasing scarcity of fossil fuels and the increasing environmental pollution, biomass energy has become an increasingly attractive alternative to fossil fuels as a renewable clean energy source, reducing greenhouse gas emissions and supporting agricultural development (Guo et al., 2016). The name "sweet sorghum" is used to distinguish those varieties of sorghum (Sorghum bicolor (L.) Moench), which accumulate high concentrations of soluble sugars like sucrose, glucose and fructose in the stem juice, from the common grain sorghum (Rao et al., 2013). Sweet sorghum is a C4 plant with a high photosynthetic rate, and has excellent characteristics such as drought resistance, waterlogging resistance, salt and alkali resistance. It has a short growing period, the use of seeds to reproduce and the amount of seeds used is much lower than that of sugar cane (Saccharum officinarum), and is suitable for sowing, so the production cost of sweet sorghum is much lower than that of sugarcane (Luo et al., 
2012; Zhang et al., 2018). Far lower than sugarcane, and suitable for sowing, so the production cost of sweet sorghum is much lower than sugarcane. And a lot of research has been carried out and will create economic benefits (Luo et al., 2012). At present, sweet sorghum is one of the most promising renewable energy sources. In recent years, sweet sorghum as a sugar crop, feed crop, energy crop and industrial crop has important significance for global economic development and environmental protection (Zhao et al., 2015; Jiang et al., 2012; Tang et al., 2012). Although sweet sorghum varieties have important agronomic traits and invaluable economic values, the high sugar metabolismrelated genes have been little known so far ( $\mathrm{Li}$ et al., 2014). Thus, it is great significance to understand the accumulation pattern of sugar in sweet sorghum and to investigate the effect of SPS gene expression on sucrose accumulation in sweet sorghum and the differences in sugar content between sweet sorghum and sorghum.

Sucrose-phosphate synthase (SPS, EC 2.4.1.14) is a key enzyme in sucrose biosynthesis in both photosynthetic and nonphotosynthetic tissues of plants. It is encoded by different gene families. SPS exists in multiple forms which show differential distributions and functional specializations in the plant tissues. The expression of SPS was higher in sugarcane as compared with maize (Zea mays L.), while in contrast no PCR amplification was obtained with the Arabidopsis plants (Arabidopsis thaliana (L.) Heynh.) (ElSayed, et al., 2013). At the transcript level, the rice (Oryza sativa L.) SPS genes, particularly SPS1, were preferentially expressed in source tissues. Diurnal changes in SPS gene expression, SPS activity, and soluble sugar content in leaf blades were investigated. The expression of all the SPS genes, particularly that of SPS1 and SPS11, tended to be higher at night when the activation state of the SPS proteins was low, and the mRNA levels of SPS1 and SPS6 were negatively correlated with sucrose content. The temporal patterns of SPS gene expression and sugar content under continuous light conditions suggested the involvement of endogenous rhythm and/or sucrose sensing in the transcriptional regulation of SPS genes (Okamura et al., 2011). The association among sucrose content, tree phenology and elevated SPS gene expression also implicates both enzyme and product in regulating poplar developmental processes (Park et al., 2009). SPS activity is highly regulated by hierarchy of mechanisms including transcriptional control (Taneja and Das, 2014). Therefore, to understand the accumulation and metabolism of sugar in plants, it is essential to study the regulation of SPS and gene expression.

Real-time PCR (real-time quantitative PCR technology) can quantify the initial template, it is simple and quick to operate, with strong specificity and high sensitivity. Because the entire process does not require post-processing of PCR products, it can effectively prevent contamination and false positives in the detection process, greatly improving the detection efficiency, and fluorescence quantification can also prevent non-specific amplification by melting curves, probes, etc. Thus, real-time PCR has the tendency to replace conventional PCR. It refers to the addition of fluorescent groups to the PCR reaction system, real-time monitoring of the entire PCR process using fluorescence signal accumulation, and finally the quantitative analyses of unknown templates using standard curves (Hou, 2009). Okamura et al. (2011) investigated the tissue- and developmental stage-specific expression patterns of the rice SPS gene family using real-time RT-PCR techniques. The diurnal changes in SPS gene expression and activity in leaves were also examined. Based on the results presented, predictions of the key transcriptional regulator of each SPS gene were discussed. Therefore, RT-PCR technology plays an important role in the determination of SPS enzyme activity. 
For sweet sorghum, sugar content is an important trait indicator. The study of the correlation between the changes of SPS activity and gene expression and sucrose content is the theoretical basis to find out the factors influencing sugar sorghum accumulation in sweet sorghum. In this study, the relationship between SPS activity and gene expression patterns and sugar accumulation was studied, which provided the theoretical basis for the selection and breeding of sweet sorghum new varieties and the determination of the best harvest stage.

\section{Research design and methods}

\section{Plant material}

Sweet sorghum LTR102 (as the female parent in this experiment), common grain sorghum 654 (as the male parent) and F5 high and low sugar plants from the cross of the first two were supplied by Liaoning Academy of Agricultural Sciences. Through subculture techniques, the genotypes were continuously purified to screen for high sugar varieties. Three replicates of each treatment were sampled to extract the sugar and determine the sugar content at the seedling stage, jointing stage, heading stage and mature stage.

\section{Determination of SPS activity}

The sample $(1 \mathrm{~g})$ was homogenized to a fine powder in pre-chilled mortar and added to $2.5 \mathrm{~mL}$ phosphate buffer (twice). These supernatant liquor were collected after centrifugation at $10,000 \mathrm{xg}\left(4^{\circ} \mathrm{C}\right)$ for $15 \mathrm{~min}$, the reaction mixture contained in a final volume of $50 \mu \mathrm{L}$ supernatant liquor, $50 \mu \mathrm{L}$ phosphate buffer, $20 \mu \mathrm{L} \mathrm{MgCl}_{2}, 20 \mu \mathrm{L}$ UDPG and $20 \mu \mathrm{L}$ 6-phosphate fructose. Then, vibrated it and incubated the tubes for $30 \mathrm{~min}$ in a water bath at $30{ }^{\circ} \mathrm{C}$. The reaction was stopped by the addition of $200 \mu \mathrm{L}$ of $\mathrm{NaOH}$ and the tubes placed in a water bath at $100{ }^{\circ} \mathrm{C}$ for $10 \mathrm{~min}$. After cooling the tubes to room temperature, the tissue sample was added to $1.5 \mathrm{~mL} \mathrm{HCl}(30 \%)$ and $0.5 \mathrm{~mL}$ resorcinol and then, the tubes placed in a water bath at $80{ }^{\circ} \mathrm{C}$ for $10 \mathrm{~min}$. After cooling the tubes to room temperature, absorbance was measured at $480 \mathrm{~nm}$.

\section{Total RNA extraction and cDNA synthesis}

Total RNA was extracted by improved Trizol method. The leaf tissue was homogenized to a fine powder in liquid nitrogen. And then added $1 \mathrm{ml}$ Trizol to each 50-100 $\mathrm{mg}$ of tissue, the sample volume should not be exceeded $100 \mu \mathrm{L}$ at room temperature for $5 \mathrm{~min}$. Then, the leaf tissue was added $0.2 \mathrm{~mL}$ chloroform to the tubes and vibrate it for $15 \mathrm{~s}$, static cultivation at room temperature for $5 \mathrm{~min}$. These supernatant liquor were collected after centrifugation at $12,000 \mathrm{xg}\left(4{ }^{\circ} \mathrm{C}\right)$ for $15 \mathrm{~min}$ and then, collected the supernate into tubes. The samples were added $0.5 \mathrm{~mL}$ isopropanol at room temperature for $5 \mathrm{~min}$. These samples were collected after centrifugation at $12,000 \mathrm{~g}\left(4^{\circ} \mathrm{C}\right)$ for $10 \mathrm{~min}$ and then, the supernatant liquor was discarded. The precipitate was added $1 \mathrm{~mL}$ ethanol to the tubes to dissolve RNA precipitate. Similarly, the samples were collected after centrifugation at $12,000 \mathrm{xg}\left(4^{\circ} \mathrm{C}\right)$ for $5 \mathrm{~min}$. If it used for reverse-transcription PCR, repeat the above steps twice (discard supernatant liquor and dissolve RNA precipitate). Dried for 5-10 min at room temperature. Then dissolved the sample by TE $(30-60 \mu \mathrm{L})$. Then take analyses of the extracted RNA purity and RNA 
integrity. RNA samples that were diluted 100-fold or 200-fold with RNase to solubilize RNA samples. Absorbance was measured at 260, 280, $230 \mathrm{~nm}$.

Determine the RNA concentration of the original sample: $\mathrm{RNA} \mu \mathrm{g} / \mu \mathrm{L}=\mathrm{A}(260,280$, $230) \times 33 \times \mathrm{T} / 1000$. A: Absorbance; T: Dilution times.

After electrophoresis on a $1.0 \%$ agarose gel at $90 \mathrm{~V}$ for $45 \mathrm{~min}$, the clarity and integrity of the RNA bands were visualized on a gel imager.

\section{Design of SPS primers}

Based on the known cDNA sequence of a sweet sorghum SPS3-1 gene coding region (Liu, 2009), primers were designed using Oligo6 software and Primer primier software (Zhang et al., 2004). And it was named SPS-1, $\beta$-Actin is the housekeeping gene (Table 1).

Table 1. Primers for SPS gene amplification

\begin{tabular}{c|c|c|c|c}
\hline Primer & $\begin{array}{c}\text { Length of } \\
\text { primer (bp) }\end{array}$ & TM & Primer sequence & Amplified length \\
\hline SPS-1 forward primer & 20 & 58 & GGCAAGAAATAGAAGAGCAG & $121 \mathrm{bp}$ \\
SPS-1 reverse primer & 20 & 58 & ACCATACGAGGCATAAAACG & \\
Actin-F forward primer & 20 & 58 & AGATGGTGTCAGCCACACTG; & $210 \mathrm{bp}$ \\
Actin-R reverse primer & 20 & 58 & CGAGCTTCTCCTTCATGTCC & \\
\hline
\end{tabular}

\section{Quantitative PCR systems and conditions}

RT-PCR was used to determine the expression of SPS in sweet sorghum. RT-PCR was performed with primers according to Table 1. The RNA from all sample was reverse transcribed using QuantiTect Reverse Transcription Kid, primed with 50 pmol of reverse primer (Oligo dT) by following the manufacturer's protocol and carried out in a PTC 100 Peltier Thermal Cycler (MJ Research, Ramsey, MN, USA).

The PCR reaction was performed in a volume of $25 \mu \mathrm{L}$ containing $10 \times$ Buffer $(2.5 \mu \mathrm{L}), 25 \mathrm{mg} / \mathrm{mL} \mathrm{MgCl}_{2}(2.5 \mu \mathrm{L}), 100 \mu \mathrm{mol} / \mathrm{L} \mathrm{dNTP}(0.5 \mu \mathrm{L}), 5 \mathrm{U} / \mu \mathrm{L}$ Taq enzyme $(0.5 \mu \mathrm{L}), 0.2 \mu \mathrm{mol} / \mathrm{L}$ Forward Primer $(1.0 \mu \mathrm{L}), 0.2 \mu \mathrm{mol} / \mathrm{L}$ Reverse Primer $(1.0 \mu \mathrm{L})$, cDNA template $(1.0 \mu \mathrm{L})$, and sterile $\mathrm{ddH}_{2} \mathrm{O}$ added up to the final volume.

This PCR program was performed with initial denaturation at $94{ }^{\circ} \mathrm{C}$ for $2 \mathrm{~min}$, (denaturation $94{ }^{\circ} \mathrm{C} 30 \mathrm{~s} \rightarrow$ annealing $53{ }^{\circ} \mathrm{C} 20 \mathrm{~s} \rightarrow$ extension $72{ }^{\circ} \mathrm{C} 80 \mathrm{~s}$ ) 32 cycles $\rightarrow$ extension $72{ }^{\circ} \mathrm{C} 10 \mathrm{~min}$ and saved at $4{ }^{\circ} \mathrm{C}$ (Yao et al., 2009; Li et al., 2007).

\section{Detection of the expression of SPS using real-time quantitative PCR}

Correlation analyses of SPS gene and housekeeping gene expression

In this experiment, Comparative Delta-delta $\mathrm{Ct}$ method was used for relative quantitative analyses of the target gene. Dilution of cDNA into 5 gradients $\left(2^{2}, 2^{4}, 2^{5}\right.$, $2^{6}, 2^{7}$ ), using SYBR Green I real-time PCR of target gene SPS and housekeeping gene $\beta$-actin. Create the standard curves for two genes and detect amplification efficiency. By calculating the difference between the two standard curves $M$ (slope) is less than 0.1, it is proved that the relative quantitative analyses can be used. 


\section{Real-time PCR reaction system and conditions}

The PCR program was performed with initial denaturation at $95^{\circ} \mathrm{C}$ for $15 \mathrm{~min}$, ten cycles of $94{ }^{\circ} \mathrm{C}$ for $20 \mathrm{~s}, 53{ }^{\circ} \mathrm{C}$ for $20 \mathrm{~s}, 72{ }^{\circ} \mathrm{C}$ for $80 \mathrm{~s}$ with 35 cycles and final $53-95{ }^{\circ} \mathrm{C}$ extension for dissolution curve program. Three replicates of each treatment were sampled to set no template negative control. The PCR product was analyzed and subjected to $1 \%$ agarose gel electrophoresis to determine the product specificity. The experimental data was processed and analyzed by SPSS software.

\section{Results}

\section{Correlation analyses of SPS activity and sucrose content}

By measuring the activity of SPS in the leaves of the male and female parents, and the F5 high sugar population and the low sugar population they hybridize, we can understand the changes of SPS among different groups in different periods. The variation of SPS was increased. At the mature stage, the activity of three sweet sorghum varieties (the female parent, high sugar individuals and low sugar individuals) reached the maximum of $14.86,17.63,13.76 \mu \mathrm{mol} / \mathrm{h}$.g.fw, respectively. The SPS activity of the male parent at the mature stage was more minor than the heading stage. In spite of the SPS activity of four species was similar at the seedling stage, the large differences in SPS activity from the jointing stage. The SPS activity of the cross of the high and low sugar individuals grew linearly, the rate of increase in activity was faster than that of the parents and high sugar varieties had the highest SPS activity at mature stage. Analyses of correlation for sucrose and SPS activities in leaves in sorghum and sweet sorghum showed that sucrose was significant positive correlation with SPS activity ( $R=0.763$, $\mathrm{P}<0.01)$ (Fig. 1).

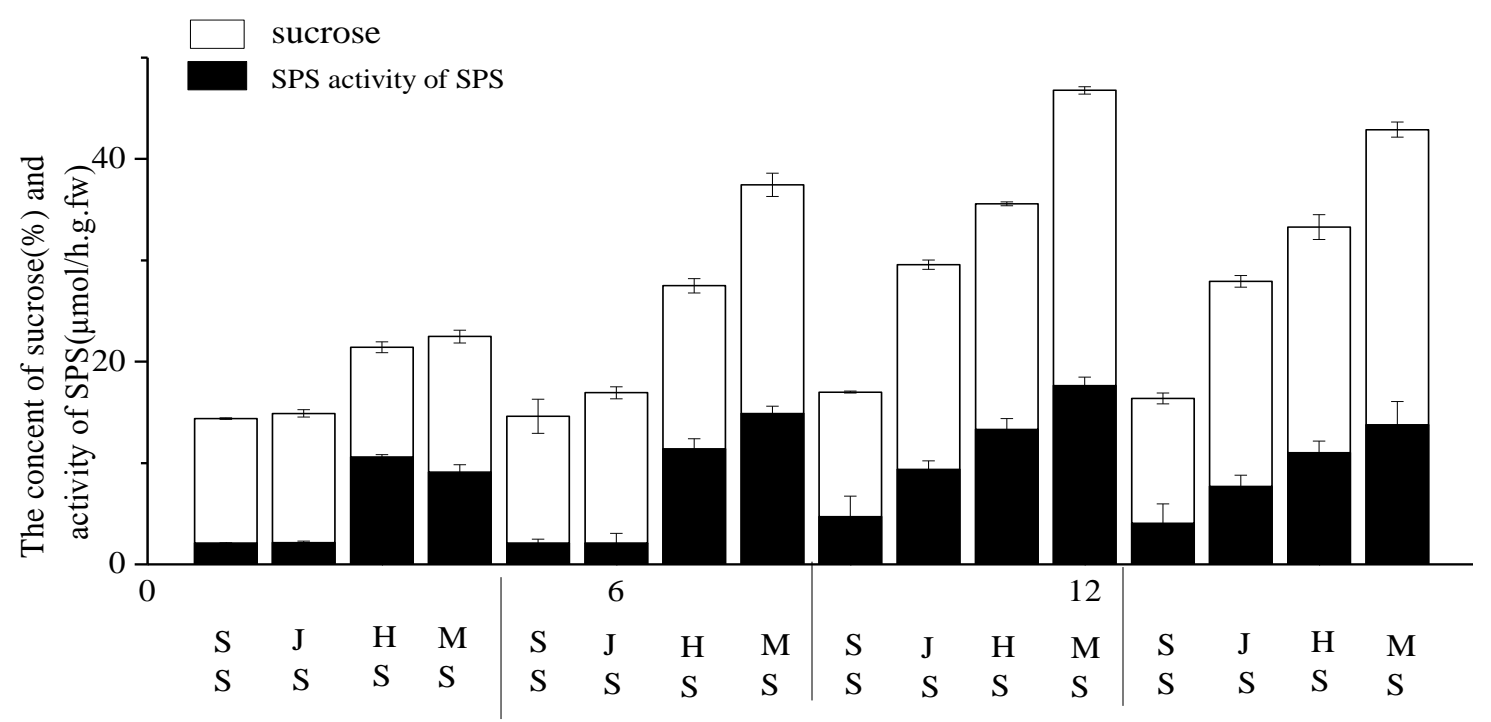

sorghum654 sweet sorghum LTR102 high sugar individuals low sugar individuals

Figure 1. The relationship between the activity of SPS and sucrose of different group at different growth stages (SS: seeding stages; JS: jointing stages; HS: heading stages; MS: mature stages) 


\section{Analyses of extraction results of RNA}

Agarose gel electrophoresis showed that the RNA extracted by the modified Trizol method had three bands, and the brightness of the $28 \mathrm{~S}$ bands in the total RNA was about twice that of the $18 \mathrm{~S}$ band, indicating that it was less degraded during the extraction process. The integrity of the extracted RNA was intact, indicating that the RNA was not contaminated and could be used as a template in the next experiment (Fig. 2).

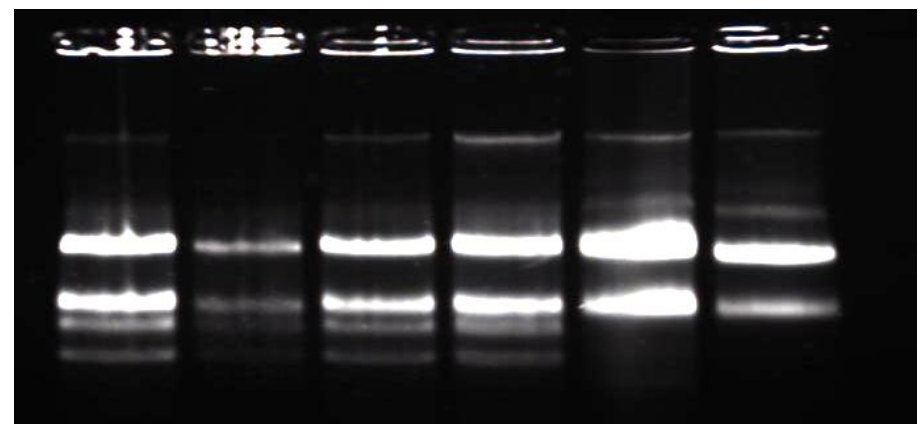

Figure 2. 1\% agarose gel electrophoresis of total RNA extracted

\section{Qualitative analyses of SPS gene expression}

At the seedling stage, parents, the SPS gene expression of F5 high and low sugar leaves (Fig. 3). In the figure, bands 1 to 4 were used as templates for the cDNAs of paternal, maternal, high-sugar and low-sugar individuals, and $\beta$-Actin was a PCR product amplified by primers. The fragment length was about $210 \mathrm{bp}$. The bands 5 and 6 were used as templates for the cDNAs of the paternal, maternal, high- and low-sugar individuals, and SPS-1 was a PCR product amplified by primers. The fragment length was $121 \mathrm{bp}$. At the seedling stage, the SPS gene has already begun to express.

SS

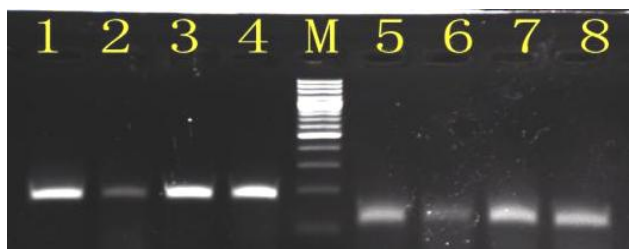

HS

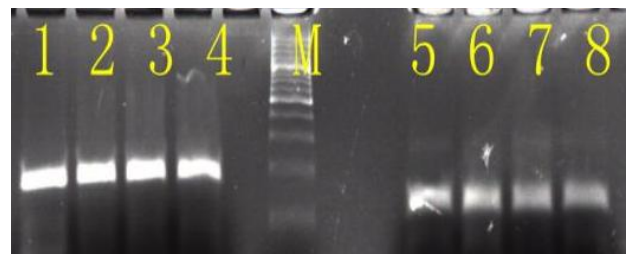

JS

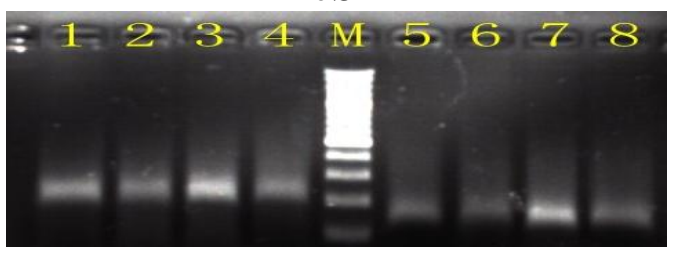

MS

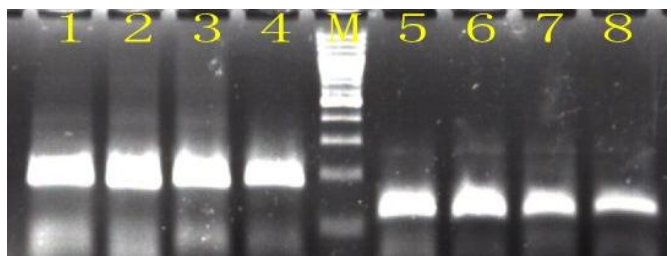

Figure 3. The electrophoresis of SPS gene and housekeeping genes at developmental stages [top left: SS (seeding stages); top right: JS (jointing stages); bottom left: HS (heading stages); bottom right: $M S$ (mature stages)]

At the jointing stage, parents, the high sugar individuals showed strong expression, and the SPS gene expression of the paternal parent at the jointing stage was not as 
strong as high sugar individuals. At the heading stage, the brightness and thickness of the target fragment were stronger than those of the previous two stages, indicating that the expression level of the SPS gene was greater than that at the seedling stage and the jointing stage. At the mature stage, the degree of brightness and thickness of the target fragment reached the maximum, which fully demonstrated that the expression level of SPS gene reached a large value during the mature stage (Fig. 3).

Using $\beta$-Actin and SPS-1 as primers, the desired target fragment can be amplified with clear. From Figure 3 we can see that the SPS gene can be detected at the seedling stage. With the extension of the growth period, the expression level of SPS gene gradually increases, and the expression level reaches the maximum at the mature stage. This is similar to the variation of sucrose content, and it can be initially demonstrated that the expression of SPS affects the accumulation of sucrose. On the basis of RT-PCR detection was performed to more accurately understand the change pattern of SPS gene.

\section{Quantitative analyses of SPS gene expression}

Comparative analyses of quantitative expression of SPS gene at seedling stage

Relative quantitative analyses of SPS gene expression in the parental, F5 high and low sugar individuals at different growth stages was performed using the Comparative Delta-delta $\mathrm{Ct}$ method. In comparison with the relative concentration of SPS gene in female leaves, the relative concentration of SPS gene in the high-growth individuals at the seedling stage was higher, which was 1.59 times that of the parental SPS gene. The relative concentration of the parental SPS gene was the minimum and was only half of the parental SPS gene expression (Table 2).

Table 2. The comparison of different breeds of the SPS gene expression at seedling stage

\begin{tabular}{c|c|c|c|c|c|c}
\hline Replicate name & GOI CT & Norm. CT & Delta CT & Delta-delta CT & Relative conc. & Calibrator \\
\hline Male parent & 25.44 & 20.30 & 5.14 & 0.88 & 0.54 & \\
Female parent & 27.09 & 21.97 & 5.12 & 0.00 & 1.00 & Yes \\
High sugar & 26.15 & 21.70 & 4.45 & -0.12 & 1.59 & \\
Low sugar & 25.59 & 20.51 & 5.07 & 0.36 & 1.03 & \\
\hline
\end{tabular}

Comparative analyses of quantitative expression of SPS gene at jointing stage

At the jointing stage, the relative concentration of SPS gene in the female parent leaves was also used as a control. The parents, F5 high sugar and low sugar plants had little difference in expression at this stage. The highest SPS gene expression level in the high-sugar individual was only 1.25 times that of the minimum low-sugar individual (Table 3).

Table 3. The comparison of different breeds of the SPS gene expression at jointing stage

\begin{tabular}{c|c|c|c|c|c|c}
\hline Replicate name & GOI CT & Norm. CT & Delta CT & Delta-delta CT & Relative conc. & Calibrator \\
\hline Male parent & 25.44 & 20.3 & 5.14 & 0.24 & 0.84 & \\
Female parent & 27.09 & 22.19 & 4.9 & 0 & 1.00 & Yes \\
High sugar & 26.37 & 21.45 & 4.83 & -0.07 & 1.05 & \\
Low sugar & 25.59 & 20.52 & 5.07 & 0.18 & 0.88 & \\
\hline
\end{tabular}




\section{Comparative analyses of quantitative expression of SPS gene at heading stage}

The relative concentration of SPS gene in the paternal leaves was the minimum, and the expression levels in the other three individuals were not significantly different. This indicated that the difference in expression levels of SPS genes between sweet sorghum and sorghum increased from the heading stage. The expression level of SPS gene in sweet sorghum was about 2 times higher than that of sorghum (Table 4).

Table 4. The comparison of different breeds of the SPS gene expression at heading stage

\begin{tabular}{c|c|c|c|c|c|c}
\hline Replicate name & GOI CT & Norm. CT & Delta CT & Delta-delta CT & Relative conc. & Calibrator \\
\hline Male parent & 24.28 & 19.09 & 5.19 & 0.88 & 0.54 & \\
Female parent & 24.39 & 20.27 & 4.31 & 0.00 & 1.00 & Yes \\
High sugar & 24.46 & 20.62 & 4.19 & -0.12 & 1.08 & \\
Low sugar & 24.62 & 19.96 & 4.66 & 0.36 & 0.78 & \\
\hline
\end{tabular}

\section{Comparative analyses of quantitative expression of SPS gene at mature stage}

At the mature stage, the relative concentration of SPS gene in the female parent leaves was used as a control. Parents, F5 high-sugar and low-sugar populations had different expression levels at this stage. The expression level of the SPS gene in the maximum high-sugar individual was approximately 15 times that of the minimum lowsugar individual (Table 5).

Table 5. The comparison of different breeds of the SPS gene expression at mature stage

\begin{tabular}{c|c|c|c|c|c|c}
\hline Replicate name & GOI CT & Norm. CT & Delta CT & Delta-delta CT & Relative conc. & Calibrator \\
\hline Male parent & 27.65 & 21.96 & 5.69 & 1.31 & 0.40 & \\
Female parent & 26.48 & 22.11 & 4.38 & 0.00 & 1.00 & Yes \\
High sugar & 26.07 & 24.28 & 1.80 & -2.58 & 5.98 & \\
Low sugar & 28.52 & 23.80 & 4.73 & 0.35 & 0.78 & \\
\hline
\end{tabular}

In summary, the relative concentration of maternal SPS gene was used as a control at each stage. The maximum expression level was high-sugar individuals, and the minimum expression level was the male parent. The order of SPS gene expression from high to low was high-sugar individuals, maternal, low-sugar group and paternal. At the mature stage, this change trend is similar to the accumulation pattern of sucrose and the change of SPS activity. It can be seen that the expression of SPS gene influences the accumulation of sucrose, and the higher the expression level of SPS gene, the higher the sucrose content.

In the test materials selected for this experiment, the male parent was the pure sorghum or hybrid sweet sorghum. At the maturing stage, the SPS gene expression was lowest in the male parent leaves, and it was up to 15 times higher than the high-sugar individual with the maximum expression. It is further explained that the difference in sucrose content is one of the causes of the difference in sugar content between ordinary sorghum and sweet sorghum. 


\section{Discussion and conclusion}

Sweet sorghum is an important sugar crop. The accumulation of sweet sorghum sugar is mainly based on sucrose. Comparing the gene expression levels of SPS at different stages of different varieties of sweet sorghum has important significance for increasing the sugar content of sweet sorghum (Ye et al., 2012). In this experiment, the improved Trizol method can propose high-quality, non-polluting RNA easily and rapidly. The qualitative analyses of the sweet sorghum SPS gene revealed that the spectrum detected at the mature stage was the most distinct, and the SPS gene expression reached the maximum level during the mature period. The correlations between sucrose and SPS activity in leaves of sorghum and sweet sorghum were analyzed. The results showed that there was a significant positive correlation between sucrose and SPS activity, and it could be initially proved that SPS gene expression was a factor affecting sucrose content.

The experiment of RNA extraction must always be careful not to degrade RNA (Zong et al., 2011). Compared with conventional PCR technology, real-time fluorescence quantitative PCR technology has high sensitivity, specificity, reproducibility, fast and simple operation, and can directly perform qualitative analyses and quantitative analyses (Liu et al., 2011). Real-time PCR technology is a very effective experimental method and has been widely used in molecular biology, genetic engineering, medical diagnosis and other fields (Ren et al., 2007). In this experiment, by analyzing the correlation between SPS gene and housekeeping gene expression, the dissolution profiles of the two genes were single peaks, indicating that the specificity of the reaction and accurate in the PCR amplification process and there are no non-specific amplifications and primer dimers. It is an ideal dissolution curve, indicating that the selected primers can be applied to Comparative Delta-delta $\mathrm{Ct}$ method relative quantitative analyses of parental, F5 high glucose and low sugar populations at different growth stages of SPS gene expression.

By comparing the changes of the relative concentrations of SPS gene in female parent at different growth stages, it can be seen that the change pattern of SPS gene in sweet sorghum is consistent with the variation law of sucrose content and SPS activity, and both of them reach the maximum value at mature stage. Yekai et al. (2012) showed that the highest value of the sorghum SPS enzyme activity appeared in the maturity stage of No. 9, which was consistent with this experiment. The correlation analyses of sucrose and SPS gene relative concentrations in leaves of sorghum and sweet sorghum showed that the relative concentration of sucrose and SPS gene was positively correlated. By understanding the changing pattern of SPS genes and providing theoretical basis for determining the selection and breeding of new sweet sorghum varieties. It is great significance to understand the laws of sugar accumulation in sweet sorghum, the principle of SPS, metabolism and regulation. It is also possible to breed sweet sorghum varieties with high sugar content to guide production practices and have good reference for other crops.

Acknowledgements. The research was partly supported by Major incubating project of Shenyang Normal University. 


\section{REFERENCES}

[1] ElSayed, A. E., Boulila, M., Rafudeen, M. S. (2013): Investigation into the expression of sucrose transporters and sucrose phosphate synthase mRNA in different plant species. Agricultural Research 2(1): 31-42.

[2] Guo, H. X., Wang, F. Y., Li, S., Miao, Y. F. (2016): Effect of different planting density and nitrogen application on growth, biomass and sugar content of sweet sorghum. - Jiangsu Agricultural Sciences 44(4): 152-154.

[3] Hou, Y. (2009): Research progress and application of fluorescence quantitative PCR. Guizhou Agricultural Sciences 37(6): 29-32.

[4] Jiang, H., Hu, R. F., Zou, J. Q., Li, Y. Y. (2012): Research progress of biomass energy sweet sorghum. - Heilongjiang Agricultural Sciences 2: 139-141.

[5] Li, Y. Y., Liu, Y., Tao, S. Y. (2007): Application of RAPD technology in genome analysis of sweet sorghum varieties. - Journal of Shenyang Normal University (Natural Science) 25(4): 499-502.

[6] Li, Y. Y., Mao, X., Yu, X., Zhang, Y. H., Ma, L. J., Li, X. M., Ma, C. Y., Hao, L. (2014): Development of a high sugar trait-related SCAR marker in sweet sorghum. - International Journal of Agriculture \& Biology 3: 668-670.

[7] Liu, C. H. (2011): Research progress and application of real-time fluorescence quantitative PCR. - China Practical Medicine 6(31): 238-240.

[8] Liu, Y. (2009): Cloning of Genes of the Key Enzymes Involved in Sugar Accumulation and Development of Functional Markers in Sweet Sorghum. - Institute of Crop Sciences, CAAS, Beijing China.

[9] Luo, S. (2012): Research progress of sweet sorghum. - Technology and Market 19(4): 292.

[10] Okamura, M., Aoki, N., Hirose, T., Yonekura, M., Ohto, C., Ohsugi, R. (2011): Tissue specificity and diurnal change in gene expression of the sucrose phosphate synthase gene family in rice. - Plant Science 181: 159-166.

[11] Park, J.-Y., Canam, T., Kang, K.-Y., Unda, F., Mansfield, S. D. (2009): Sucrose phosphate synthase expression influences poplar phenology. - Tree Physiology 29: 937-946.

[12] Rao, P. S., Kumar, C. G., Reddy, B. V. S. (2013): Sweet Sorghum: From Theory to Practice. - In: Rao, P. S., Kumar, C. G. (eds.) Characterization of Improved Sweet Sorghum Cultivars. - Springer Briefs in Agriculture, Springer, India, pp: 1-15.

[13] Ren, G. K., Wang, Y. Y. (2007): Research progress of real-time fluorescence quantitative PCR. - Clinical Medicine Practice Journal 16(4): 243-245.

[14] Taneja, D., Das, N. (2014): Molecular cloning, sequence, and expression studies of sucrosephosphate synthase in the potato (Solanum tuberosum L.) cultivars. - Acta Physiol Plant 36: 2253-2269.

[15] Tang, S. Y., Xi, Z. X., Xie, Q. (2012): Sweet sorghum in the development of bio-energy industry. - Current Biotechnology 2(2): 81-86.

[16] Yao, Y., Chen, Y. S., Li, F. S. (2009): Optimization of RAPD-PCR system and amplification program of dwarf caster. - Chin J Biologicals March 22(3): 284-287.

[17] Ye, K, Zaitunigui Kuerban, Chen, W. (2012): Research on activity of SS and SPS in sweet sorghum sowed on different dates. - Xinjiang Agricultural Science 49(10): 1874-1880.

[18] Zhang, G. Q., Ge, Y. B., Zhang, Z. Y., He, C. G. (2018): A Review of drought resistance of sorghum. - Gansu Agr. Sci. and Techn 6: 67-72.

[19] Zhang, X. Y., Gao, Y. N. (2004): To design PCR primers with Oligo 6 and Primer Premier 5. - China Journal of Bioinformatics 2: 15-46.

[20] Zhao, H., Zhai, G. W., Zou, G. H. (2015): Comparison of substance accumulation and distribution changes between sweet sorghum and ordinary sorghum. - Acta Agriculturae Zhejiangensis 27(1): 7-11.

[21] Zong, C. Z. (2011): Analysis of factors affecting RNA isolation qualities. - Journal of Guangxi Agriculture 26(1): 31-34. 